\title{
Porous high-density polyethylene in functional rhinoplasty: Excellent long-term aesthetic results and safety
}

\author{
Young Hyo Kim MD PhD, Tae Young Jang MD PhD
}

\begin{abstract}
YH Kim, TY Jang. Porous high-density polyethylene in functional rhinoplasty: Excellent long-term aesthetic results and safety. Plast Surg
\end{abstract} 2014;22(1):14-17.

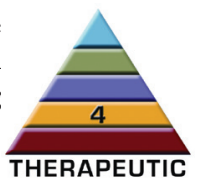

BACKGROUND: Experience with the use of porous high-density polyethylene (PHDPE) for reconstruction of the nasal framework has been limited. OBJECTIVE: To confirm the safety and utility of PHDPE by analyzing aesthetic outcomes and assessing the frequency of complication related to PHDPE in a large, population-based, long-term follow-up study.

METHODS: A total of 151 patients who had undergone septoplasty and/or functional rhinoplasty using PHDPE were enrolled. PHDPE sheets were used for diverse purposes such as septal extension graft, spreader graft, columellar strut or dorsal augmentation graft. After a long-term follow-up period (mean $[ \pm \mathrm{SD}] 39.5 \pm 27.8$ months; range six to 101 months), postoperative aesthetic outcome was evaluated objectively (by independent surgeons) and subjectively (patient self-report). Complications related to PHDPE were estimated through review of medical records.

RESULTS: The most common use of the PHDPE graft was for septal extension $(n=80[42.6 \%])$ and spreader graft $(n=58$ [30.9\%]). Results of aesthetic evaluation by surgeons were excellent in 61 cases $(40.4 \%)$, good in $54(35.8 \%)$ and fair in $34(22.5 \%)$. According to patient selfreport, 100 were 'satisfied' (66.2\%) and 36 rated their new profile as 'better than the preoperative profile' $(23.8 \%)$. Complications were reported in six cases (4.0\% [five cases of extrusion and one case of infection]). All complications were resolved after the surgical removal of PHDPE sheets under local anesthesia.

CONCLUSION: The present study demonstrated that PHDPE could be used in functional primary rhinoplasty with excellent long-term aesthetic results and safety.

Key Words: Aesthetics; Polyethylenes; Postoperative complications; Rhinoplasty

\author{
Un polyéthylène poreux de haute densité pour une \\ rhinoplastie fonctionnelle : une innocuité et des résultats \\ esthétiques extrêmement satisfaisants à long terme
}

HISTORIQUE : L'expérience relative à l'utilisation de polyéthylène poreux de haute densité (PÉPHD) pour la reconstruction de la structure nasale est limitée.

OBJECTIF : Confirmer l'innocuité et l'utilité du PÉPHD par l'analyse des résultats esthétiques et l'évaluation de la fréquence des complications qui y sont liées dans le cadre d'une vaste étude de suivi à long terme en population.

MÉTHODOLOGIE : Au total, 151 patients qui avaient subi une septoplastie ou une rhinoplastie fonctionnelle au moyen de PÉPHD ont participé à l'étude. Les feuilles de PÉPHD ont été utilisées à plusieurs fins, telles qu'une greffe d'expansion de la cloison nasale, une greffe d'écartement, un étai columellaire ou une greffe d'augmentation dorsale. Après un suivi à long terme (moyenne [ \pm ÉT] 39,5 $\pm 27,8$ mois; plage de six à 101 mois), les résultats esthétiques postopératoires ont été évalués de manière objective (par des chirurgiens indépendants) et subjective (par les patients mêmes). Les complications liées au PÉPHD ont été évaluées d'après l'examen des dossiers médicaux.

RÉSULTATS : La greffe de PÉPHD était surtout utilisée pour l'expansion de la cloison nasale $(\mathrm{n}=80[42,6 \%])$ et la greffe d'écartement $(\mathrm{n}=58[30,9 \%])$. Les chirurgiens ont jugé les résultats esthétiques excellents dans 61 cas (40,4\%), bons dans 54 cas $(35,8 \%)$ et corrects dans 34 cas (22,5\%). Cent patients se sont dits « satisfaits » $(66,2 \%)$ et 36 ont classé leur nouveau profil comme « meilleur que le profil préopératoire » $(23,8 \%)$. Six cas ont présenté des complications (4,0\% [cinq cas d'extrusion et un cas d'infection]), qui se sont toutes résolues après l'extraction chirurgicale des feuilles de PÉPHD sous anesthésie locale.

CONCLUSION : La présente étude a démontré que le PÉPHD pouvait s'associer à une innocuité et à des résultats esthétiques à long terme extrêmement satisfaisants dans le cadre d'une rhinoplastie primaire fonctionnelle.

rhinoplasty. In fact, experience with the use of PHDPE for reconstruction of the nasal framework remains limited $(3,11,13)$. Therefore, we aimed to confirm the safety and utility of PHDPE by analyzing aesthetic outcomes and assessing the frequency of complications related to PHDPE in a large population-based, long-term follow-up study. In addition, we aimed to propose the 'ideal' use of PHDPE in functional rhinoplasty to avoid complications based on our experience and review of the relevant literature.

\section{Patients}

\section{METHODS} with severe nasal deformity such as platyrrhine nose $(6,7)$. More recently, some researchers have also attempted procedures such as septal extension grafts, spreader grafts or dorsal augmentation grafts in patients who have undergone primary rhinoplasty $(8-10)$.

However, there have been several reports of PHDPE-related complications including extrusion or infection (6), mobility of the graft $(7)$, revision or removal of the graft $(6,11)$ and, rarely, fracture of the dorsal implant (12). Given these reports, some practitioners are unwilling to use PHDPE as alloplastic material in performing
A total of 151 patients (110 male and 41 female; mean [ \pm SD] age $34.5 \pm 13.0$ years; range 16 to 70 years) who had undergone septoplasty and/or functional rhinoplasty using PHDPE (Medpor, Porex Surgical Inc, USA) between March 2004 and September 2012 were enrolled. The mean follow-up period after surgery was $39.5 \pm 27.8$ months (range six to 101 months). The present study was approved by the Inha University Institutional Review Board Committee on Studies Involving Human Beings (Incheon, Korea).

Department of Otorhinolaryngology-Head and Neck Surgery, Inha University College of Medicine, Incheon, Korea

Correspondence: Dr Tae Young Jang, Department of Otorhinolaryngology-Head and Neck Surgery, College of Medicine, Inha University,

3-Ga Shinheung-dong, Jung-Gu, Incheon, Republic of Korea, 400-711. Telephone 82-32-890-3471, fax 82-32-890-3580,

e-mail jangty@inha.ac.kr 

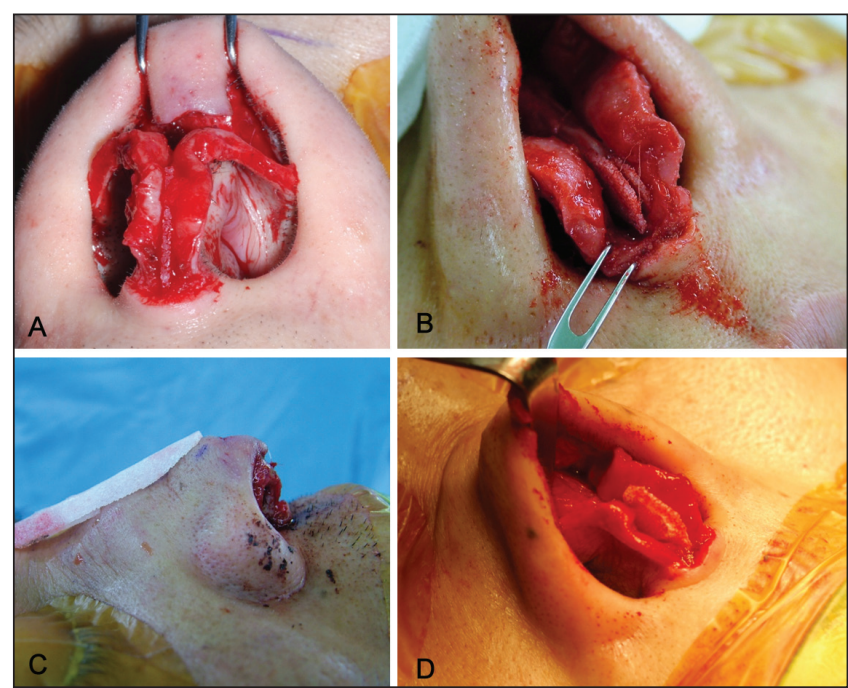

Figure 1) Examples of porous high-density polyethylene as columellar strut (A), bilateral spreader graft (B), dorsal augmentation graft (C) and septal extension graft (D)

\section{Surgical techniques}

All rhinoplasty operations were performed by a single experienced surgeon (TYJ). Open rhinoplasty techniques under general anesthesia were used in all cases. After the transcolumellar incision (inverted-V shaped) with bilateral marginal extension, the supra-perichondrial flap was elevated, exposing the osseocartilagenous skeleton. After exposure of the septal cartilage by bilateral subperichondrial septal flap, the septal deviation was corrected. The septal cartilage was harvested, preserving the L-strut. Sterilized PHDPE sheets were prepared for use for any purpose (septal extension graft, spreader graft, columellar strut or septal batten graft, etc) during the surgical procedure (Figure 1). More specifically, bilateral PHDPE was placed along the dorsal side of the L-strut for spreader graft. For the septal extension graft, PHDPE was carved to achieve ideal projection and rotation of the nasal tip. PHDPE sheets were modified according to use and were fixed to adjacent cartilage using 5/0 polydioxanone (PDS) suture.

\section{Postoperative assessments}

For objective cosmetic assessment, two independent rhinoplasty surgeons who were blinded to the aim of the present study reviewed the preoperative and the most recent postoperative photographs of the patients. They graded their decisions as 'excellent', 'good', 'fair' or 'poor' in each case. For subjective cosmetic assessment, patients reported their degree of satisfaction as 'satisfied', 'better than preoperative' and 'dissatisfied'.

To assess complications, each patient's medical record was reviewed for any event of extrusion, infection or inflammation, dislocation, fracture and history of revision surgery because of these complications.

\section{Purpose of PHDPE}

\section{RESULTS}

Because more than one sheet of PHDPE was used in some patients (eg, for septal extension graft and spreader graft in a single patient), a total of 188 sheets were used. The most common uses of the PHDPE graft were for septal extension $(n=80[42.6 \%])$ and spreader $(n=58[30.9 \%])$. In addition, columellar strut $(n=33[17.6 \%])$, septal repair $(n=9$ [4.8\%]) and septal batten graft $(n=5[2.7 \%])$ were other indications for PHDPE sheets (Table 1).

Cosmetic assessments

Objective cosmetic assessment by rhinoplasty surgeons showed excellent outcome in $61(40.4 \%)$ patients (Figure 2), good outcome in $54(35.8 \%)$

\section{TABLE 1}

Use of porous high-density polyethylene (PHDPE) for various purposes during rhinoplasty ( $n=188$ sheets)

\begin{tabular}{lc}
\hline Purpose of PHDPE use & Grafts, $\mathbf{n}(\%)$ \\
\hline Septal extension graft & $80(42.6)$ \\
Spreader graft & $58(30.9)$ \\
Columellar strut & $33(17.6)$ \\
Septal repair & $9(4.8)$ \\
Septal batten graft & $5(2.7)$ \\
Dorsal augmentation graft & $3(1.6)$ \\
\hline
\end{tabular}

(Figure 3), fair in 34 (22.5\%) and poor in two (1.3\%). The reasons for poor outcomes were visible columellar scar in one patient and acute nasolabial angle in spite of tip surgery in another.

Subjective cosmetic assessment by patient self-report showed that $100(66.2 \%)$ were 'satisfied', $36(23.8 \%)$ reported 'better than the preoperative profile' and 15 (9.9\%) were 'dissatisfied'. Among these 15 patients, only eight, who also experienced postoperative functional problems or who strongly wanted surgical management, underwent revision surgery.

\section{Complications}

During the entire follow-up period, complications were reported in six patients $(4.0 \%)$. The most common complications were extrusion of the graft through the septal mucosal defect (four cases of spreader grafts and one case of septal extension graft) (Figure 4). Infection related to the graft was also reported in one case of dorsal augmentation graft. There was no report of dislocation or fracture. All of these complications were completely resolved after the surgical removal of PHDPE sheets under local anesthesia. There was no significant adhesion or profound hemorrhage during removal. After the revision surgery, all patients were satisfied with their results.

\section{DISCUSSION}

Autogenous tissue augmentation has several disadvantages, including donor site morbidity, prolongation of operation time and absorption of grafts during the long-term follow-up period. Therefore, several researchers have attempted to find ideal alloplastic material with longterm stability and fewer postoperative complications. To the best of our knowledge, the present study was the first to analyze the long-term aesthetic outcomes and complications in $>150$ patients who underwent functional primary rhinoplasty using PHDPE.

Because PHDPE has a highly stable structure, it is not absorbed or degraded even after a long period of time. Therefore, reconstruction of the nasal framework using PHDPE was reported to show functionally and cosmetically satisfactory results up to 18 months follow-up (13). These results were also supported by those of other researchers (6). More specifically, septal extension grafts and spreader grafts using PHDPE yielded excellent cosmetic and functional outcomes $(8,14)$. In the present study, we have also demonstrated excellent aesthetic results using PHDPE for septal extension graft and spreader graft in a large majority of our patients during a follow-up period of more than three to 8.5 years.

PHDPE forms a highly stable complex through the process of rapid ingrowth of vascularized tissue. Therefore, it has been known to be more resistant to extrusion or infection (15). According to several reports, complications of extrusion or infection were as high as $7.4 \%$ $(11,13,15,16)$. In the present study, the overall complication rate, including extrusion and infection, was $4.0 \%$. On the other hand, the use of Gore-tex (WL Gore \& Associates, USA) has an infection rate as high as $10 \%(17)$. Another alloplastic material, silicone, has very high extrusion and removal rates (25\% each) (18). In a meta-analysis comparing the complication rates among these alloplastic materials, no significant differences were observed in extrusion or infection rates. As for removal rates, PHDPE and Gore-tex showed significantly lower 


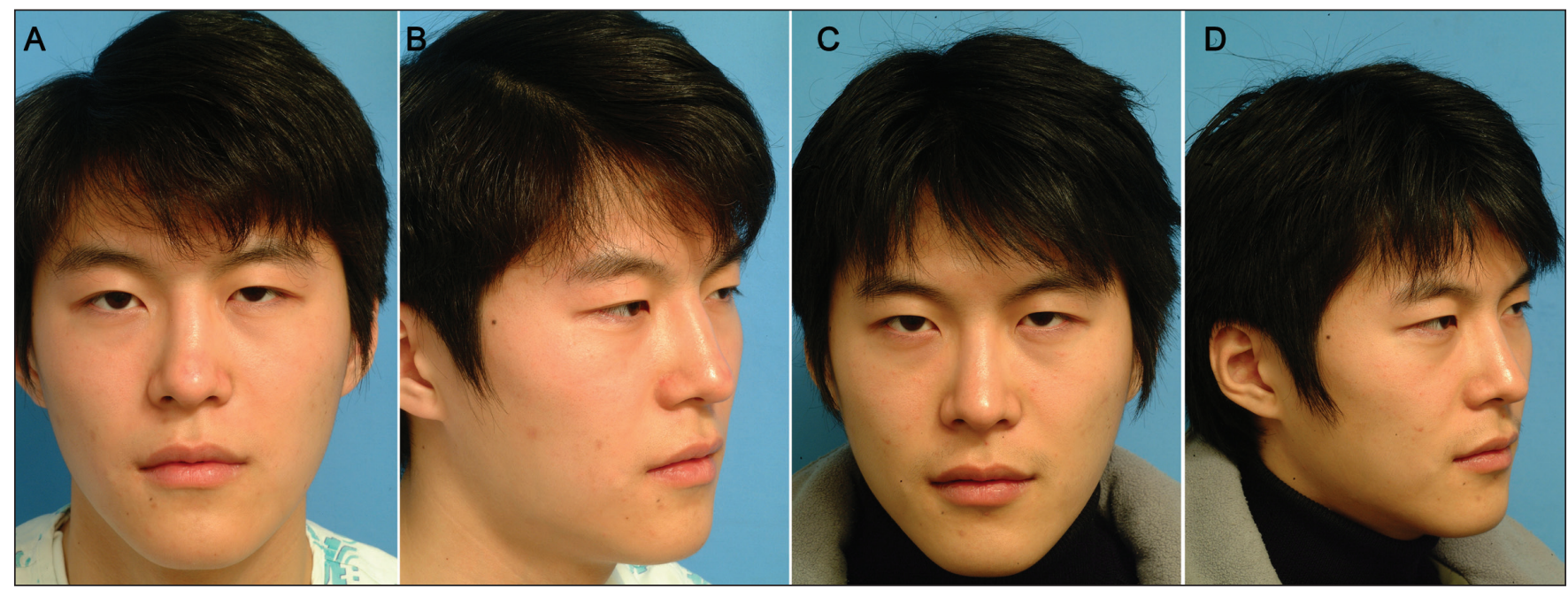

Figure 2) Example of excellent surgical outcome. A and B Preoperative; C and D 24 months postoperatively. During rhinoplasty, porous high-density polyethylene was used for spreader graft in this 21-year-old patient

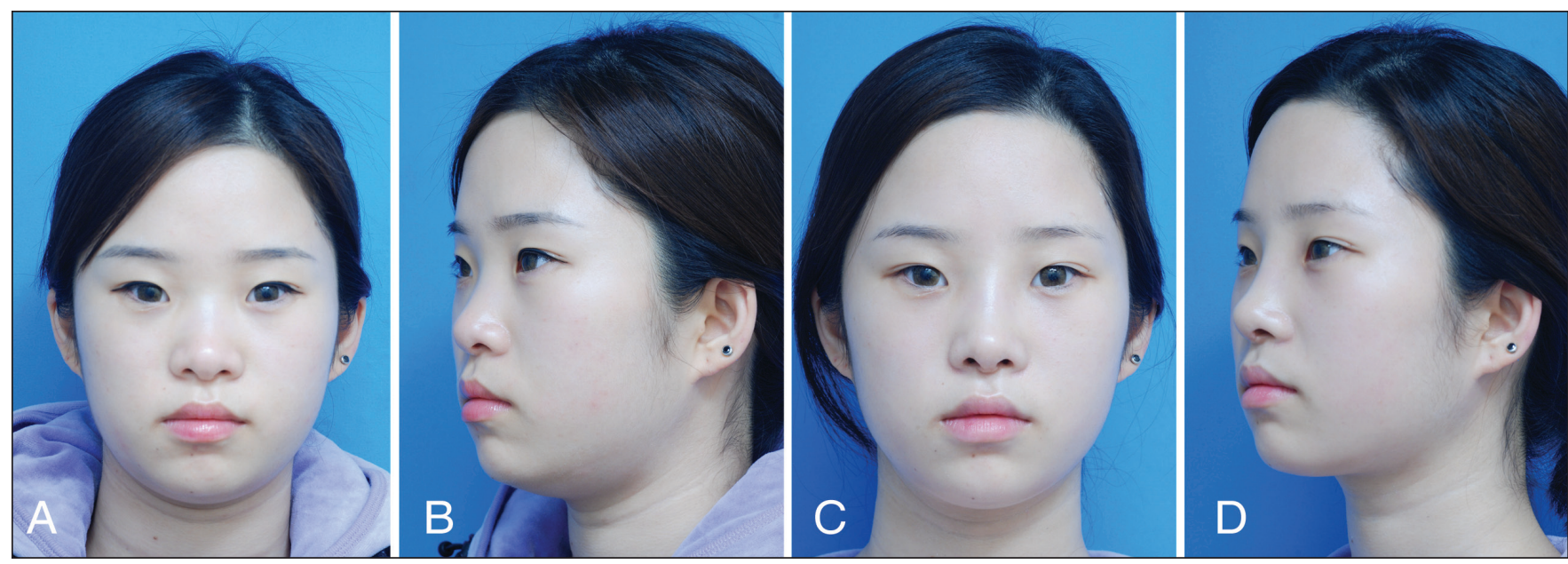

Figure 3) Example of good surgical outcome. A and B Preoperative; C and D 12 months postoperatively. During rhinoplasty, porous high-density polyethylene was used for septal extension graft in this 24-year-old patient

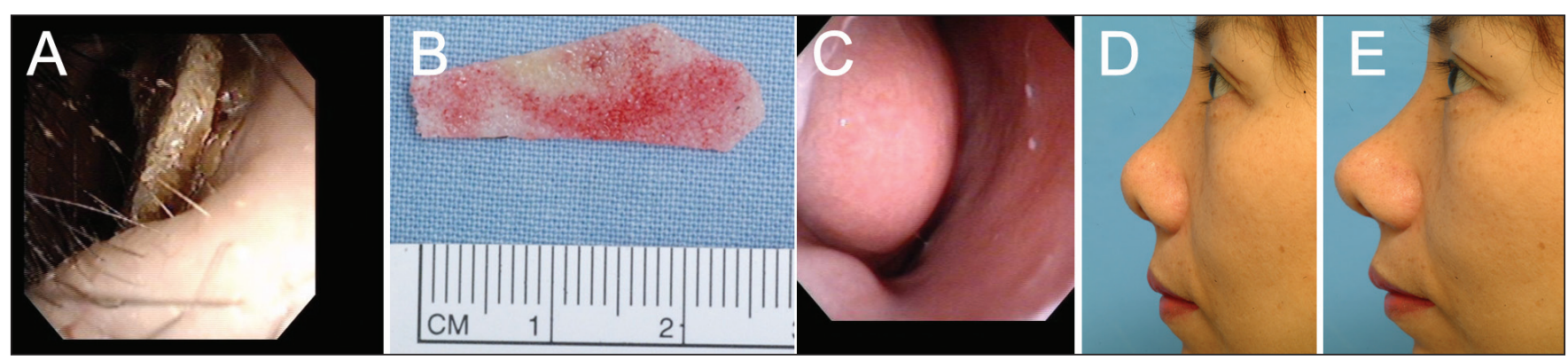

Figure 4) A Spreader graft using porous high-density polyethylene (PHDPE) was extruded through the mucosal defect. B Extruded PHDPE was completely removed without difficulty under local anesthesia. C After removal, the septal mucosa healed with no further complication. Compared with the photo before PHDPE removal (D), the nasal contour after the surgical removal (E) showed no significant change

values compared with silicone (1). Therefore, it can be presumed that PHDPE is a very safe alloplastic material compared with other widely accepted materials.

There has been significant controversy regarding the use of PHDPE for dorsal augmentation grafts in rhinoplasty. Karnes et al (10) suggested that PHDPE could be an ideal alloplastic material in failed cases with silicone implants or in cases requiring substantial strength. Razmpa et al (19) also suggested that PHDPE could be useful when used with irradiated homologous rib cartilage in augmentation rhinoplasty. However, higher complication rates were reported for PHDPE grafts used in the nasal dorsum compared with other regions (15). In addition, as the porous surface area of PHDPE increases, there is a greater risk for infection (6). Niechajev (7) also argued that use of the PHDPE nasal dorsal augmentation graft resulted in long-lasting mobility of grafts at the radix area. Gentile et al (20) also reported that dorsal augmentation using PHDPE had low resistance to infection and variable degree of absorption, causing cosmetic dissatisfaction and reoperation rates as high as $9.1 \%$. In our study, all three patients with 
dorsal augmentation grafts using PHDPE complained of a visible graft edge over the nasal arch and a continuous sense of a foreign body over the nasal dorsum. In one of three cases, removal of the graft was required because of significant infection. Therefore, we suggest that the safety of PHDPE as a nasal dorsal augmentation graft remains questionable.

It is widely accepted that complications associated with PHDPE use are 'site-related'. Subperiosteal insertion of PHDPE grafts over a rigid, bony surface (such as the chin or malar eminence) is generally benign. On the other hand, regions with thin tissue coverage, such as the nose and ear, have higher rates of extrusion or displacement (7). However, the specific subregion or conditions that could cause more complications in the nose itself remain unclear. In our study, five cases of extrusion occurred in 138 septal extension or spreader grafts. In all five of these patients, there was significant tearing of the septal mucosal flap during the septoplasty, without exception. In particular, the PHDPE

\section{REFERENCES}

1. Peled ZM, Warren AG, Johnston P, Yaremchuk MJ. The use of alloplastic materials in rhinoplasty surgery: A meta-analysis. Plast Reconstr Surg 2008;121:85e-92e.

2. Sclafani AP, Thomas JR, Cox AJ, Cooper MH. Clinical and histologic response of subcutaneous expanded polytetrafluoroethylene (Gore-Tex) and porous high-density polyethylene (Medpor) implants to acute and early infection. Arch Otolaryngol Head Neck Surg 1997;123:328-36.

3. Romano JJ, Iliff NT, Manson PN. Use of Medpor porous polyethylene implants in 140 patients with facial fractures. J Craniofac Surg 1993;4:142-7.

4. Rubin PA, Bilyk JR, Shore JW. Orbital reconstruction using porous polyethylene sheets. Ophthalmology 1994;101:1697-708.

5. Lin AY, Kinsella CR Jr, Rottgers SA, et al. Custom porous polyethylene implants for large-scale pediatric skull reconstruction: Early outcomes. J Craniofac Surg 2012;23:67-70.

6. Niechajev I. Porous polyethylene implants for nasal reconstruction: Clinical and histologic studies. Aesthetic Plast Surg 1999;23:395-402.

7. Niechajev I. Facial reconstruction using porous high-density polyethylene (Medpor): Long-term results. Aesthetic Plast Surg 2012;36:917-27.

8. Gürlek A, Celik M, Fariz A, Ersöz-Oztürk A, Eren AT, Tenekeci G. The use of high-density porous polyethylene as a custom-made nasal spreader graft. Aesthetic Plast Surg 2006;30:34-41.

9. Pham RT, Hunter PD. Use of porous polyethylene as nasal dorsal implants in Asians. J Cosmet Laser Ther 2006;8:102-6.

10. Karnes J, Salisbury M, Schaeferle M, Beckham P, Ersek RA. Porous high-density polyethylene implants (Medpor) for nasal dorsum augmentation. Aesthet Surg J 2000;20:26-30. grafts were more readily extruded when the margins of the grafts were close to the mucosal defect. Therefore, we suggest that to avoid the complication of extrusion, surgeons should take more care to preserve the septal mucosal flap during the septoplasty procedure. When the flap is torn extensively, we would consider materials other than PHDPE. Further studies of these techniques to reduce extrusion of PHDPE could yield more meaningful conclusions in the near future.

We demonstrated that PHDPE could be used in functional primary rhinoplasty with excellent long-term aesthetic results and safety.

DISCLOSURES: The authors have no financial disclosures or conflicts of interest to declare.

ACKNOWLEDGEMENTS: This study was supported by an Inha University Research grant.

11. Romo T 3rd, Sclafani AP, Sabini P. Use of porous high-density polyethylene in revision rhinoplasty and in the platyrrhine nose. Aesthetic Plast Surg 1998;22:211-21.

12. Oztürk S, Sengezer M, Coskun U, Zor F. An unusual complication of a Medpor implant in nasal reconstruction: A case report. Aesthetic Plast Surg 2002;26:419-22.

13. Türegün M, Sengezer M, Güler M. Reconstruction of saddle nose deformities using porous polyethylene implant. Aesthetic Plast Surg 1998;22:38-41.

14. Kim YH, Kim BJ, Jang TY. Use of porous high-density polyethylene (Medpor) for spreader or extended septal graft in rhinoplasty: Aesthetics, functional outcomes, and long-term complications. Ann Plast Surg 2011;67:464-8.

15. Wellisz T. Clinical experience with the Medpor porous polyethylene implant. Aesthetic Plast Surg 1993;17:339-44.

16. Yaremchuk MJ. Facial skeletal reconstruction using porous polyethylene implants. Plast Reconstr Surg 2003;111:1818-27.

17. Godin MS, Waldman SR, Johnson CM Jr. Nasal augmentation using Gore-Tex. A 10-year experience. Arch Facial Plast Surg 1999;1:118-21.

18. Lipshutz H. A clinical evaluation of subdermal and subcutaneous silicone implants. Plast Reconstr Surg 1966;37:249-50.

19. Razmpa E, Saedi B, Mahbobi F. Augmentation rhinoplasty with combined use of Medpor graft and irradiated homograft rib cartilage in saddle nose deformity. Arch Iran Med 2012;15:235-8.

20. Gentile P, Bottini DJ, Cervelli V. Reconstruction of the nasal dorsum with Medpor implants. J Craniofac Surg 2007;18:1506-8. 